\title{
FM Service Delivery and Quality Service Measurement in Public High Rise Residential Buildings in Nigeria: The Use of SERVQUAL and Satisfaction Index
}

\author{
Olusegun Olaopin Olanrele ${ }^{1} \&$ Esther Oromidayo Thontteh ${ }^{2}$ \\ ${ }^{1}$ Department of Estate Management, Faculty of Built Environment, University of Malaya, Kuala Lumpur, \\ Malaysia \\ ${ }^{2}$ Department of Estate Management, University of Lagos, Akoka, Lagos, Nigeria \\ Correspondence: Olusegun Olaopin Olanrele, Department of Estate Management, Faculty of Built Environment, \\ University of Malaya, 50603, Kuala Lumpur, Malaysia. Tel: 60-19-652-0401. E-mail: \\ olanrelesegun@yahoo.com
}

Received: October 23, 2013

Accepted: July 14, 2014 Online Published: August 29, 2014

doi:10.5539/jms.v4n3p145

URL: http://dx.doi.org/10.5539/jms.v4n3p145

\begin{abstract}
This research assessed and compared the delivery of facilities management services in public high rise residential buildings in Lagos, Nigeria. The objectives include the examination of service delivery method, assessment of the quality of service and determination of resident's satisfaction of the FM services. The methodology adopted is quantitative research and data were collected with use of questionnaire. The response options to the questions were ranked using the 5-point Likert scale. A total of 111 questionnaires were served in the two case studies. However, only 84 were retrieved, 57 from Eko Court and 27 from Boyle Street. Cumulatively $75.67 \%$ of the questionnaires were filled and retuned. The study finds that most of the services expected in high rise buildings are available in the case studies and the services are outsourced. The residents of the estates are relatively satisfied with the quality of service they are being provided with. However, the Eko Court residents exhibited a higher level of satisfaction. This infers that the quality of services provided in Eko Court is relatively better than what is obtainable in Boyle Street. The difference in level of satisfaction between the two estates is attributed to location and social class of people residing in the estates. The expectation of the residents with regards to each service is also a factor. The study recommends improved standardization of services, customized services and management of customer's expectation as ways of improving service delivery.
\end{abstract}

Keywords: FM., quality service, SERVQUAL, user satisfaction

\section{Introduction}

A residential high-rise building can be defined as vertical construction on an area of land comprising modern buildings of similar types, built together in a planned way, developed for residential purposes and owned by individuals or organisations - public or private. Assessment of its performance should therefore be an inevitable exercise for the facility managers in order to maximise the benefits of dwelling houses and create added value to the occupants. A quality service delivery in high rise building contributes in no small measure to the success of the project and the level of service quality can be assessed through feedback from the occupants of the building with the application of performance evaluation techniques to the buildings being studied. Measuring performance involves establishing the level at which set goals are met, it is a measure of quality service, satisfaction of users/customers or the difference in income and cost (Kotler, 1984; Slack, 1991; Neely, 1994; Lee et al., 2005). Performance measurement contributes more to efficient and effective service delivery in property management and maintenance to meet the expectation of occupants/users (Jeffres \& Dobos, 1995). Different methods of measuring performance were analysed by past authors and an attempt was made to group them in line with their functions (Giese \& Cote, 2002; Johnston \& Clark, 2005; Kincaid, 1994). Furthermore, quality residential high-rise buildings, like any other product or service, is adjudged by the extent to which the building meets consumer's needs and expectations - physically, socially and psychologically. Such quality of dwelling provided either by public or private organisation for rental or outright purchase, can be assessed 
through occupants' perception. Moreover, the construction industry (and indeed the housing sector) has recognised quality and client's satisfaction as major factors for business growth. However, it is still unknown how well the industry/sector is meeting the satisfaction of occupiers who may or may not be the direct client (Torbika \& Stroh, 1989). Hence, this research is concerned with post-occupancy assessment as it relates to occupiers' satisfaction on quality of performance of residential buildings. The feedback of the occupiers with regard to their satisfaction was used to assess the quality of the selected high-rise buildings and the results go towards developing a benchmark or yardstick for service quality improvement in residential high-rise buildings. It will help both the public and private developers to provide better residential buildings for users/occupiers and assist in providing healthy, productive and comfortable in/outdoor environment and long-term benefits to occupants. Moreover, in order to assess satisfaction, performance must first be measured (Francescato, Weidemann, \& Anderson, 1989). Since there are multiple aspects of performance, the use of the object of evaluation determines, to a large extent, the aspects of performance that need to be measured.

\subsection{Statement of Problem}

FM service providers are under pressure to provide a user/customer driven services and constant improvement in building performances. However, with the meager financial resource constraints, FM service organizations strive harder to manage the building, its facilities and provide services to meet the expectation of the occupants. It has become inevitable that residents' expectations are understood and measured in FM service provision. The increased demand for service apartment (flats) by foreigners, expatriates and the high income group of the Nigerian society in areas like Victoria Island and Ikoyi in Lagos not minding the high rental values made this researcher to believe that some user expectations are met by the owners/developers of service apartments. Most of these service flats are high rise blocks of flats developed by private and public developers. The choice of residential satisfaction as a criterion is governed by a number of considerations, one of which stresses the point of view of the inhabitants themselves. This emphasis is based on the effect of past neglects of the users' point of view in FM service provision which have resulted in inefficient service delivery in Nigeria. In addition, residential satisfaction reflects the inhabitants' feelings of achieving their housing objective. This is based on the Expectancy-Value Model of Attitude proposed by Robathan (1996) in which evaluations were seen as strongly dependent upon people's expectations or beliefs. Also Francescato et al. (1989) affirmed that it is a measure of the degree to which a housing (quality) performance is meeting the occupants expectation in terms of benefits and needs.

\subsubsection{Research Question}

- What are the strategies and processes of performance measurement?

- Does service quality gap reflect occupier's perception of quality service delivery in high rise buildings?

\subsection{Study aim and Objectives}

The primary purpose of the study is to identify users' satisfaction level relative to the FM service dimension and their indicators as identified by Parasuraman, Zeithaml, and Berry (1990), with particular reference to the selected properties. The objectives towards achieving this aim include the following.

1) To examine FM service delivery method adopted in the case studies.

2) To assess the service quality provision from the view of the occupiers of the selected buildings

3) To assess through ranking, the degree of importance of quality performance criteria to occupiers' satisfaction or otherwise.

4) To identify the gap(s) in the expectation and perception of service quality of the residents.

\subsection{Importance of the Study}

A high-rise building is a multi-storey/multi-floors development, taller than the maximum height people can walk up on staircases (RICS Foundation, 2009). Access to upper floors therefore requires mechanical vertical transportation. These include a variety of real properties used as residential apartments, hotels and offices, retail shops and educational facilities. The general lack of adequate land for housing development in Lagos metropolis has encouraged the vertical method of construction of residential buildings, hitherto peculiar to commercial needs and economic value. The cost implication of maintenance in terms of repair work, service provision and delivery relative to the satisfaction of the users, policy formulation, implementation and their impacts on the aggregate economy justifies this study. 


\section{Literature Review}

\subsection{The Integrated Gap Approach}

The integrated gap approach of Parasuraman, Zeithaml, and Berry (1998) was developed for the purpose of analyses of the source of problems relating to service quality which will help FM managers in rendering an improved service. The model illustrates the 'how; and 'where' problems in quality service delivery arises (fig. 1). While the customer related problems are described with the upper part, the lower part of the model specifies providers related problems in service delivery. The expectation of the customer/users related to their past experiences, communication/information and personal need. Perception on the other end relied on the effectiveness of decision and relevant actions towards quality service delivery. The management of the FM service provider is therefore expected to identify the customers' expectation for a good decision on quality specification of services (Amaratunga \& Baldry, 2003; Ling \& Chong, 2005). In most cases, it is the customer who feels the service rendered by a provider, thus communication is expected to make customer perceive service as satisfactory and this must be integrated into the steps of planning and analyses of service quality (Amaratunga \& Baldry, 2003). The gap between customers' expectation and perception of a service determines the satisfaction level of a rendered service and could be a function of some other gaps or deficiencies in the process (Ibem, 2012) as summarized in figure 1.

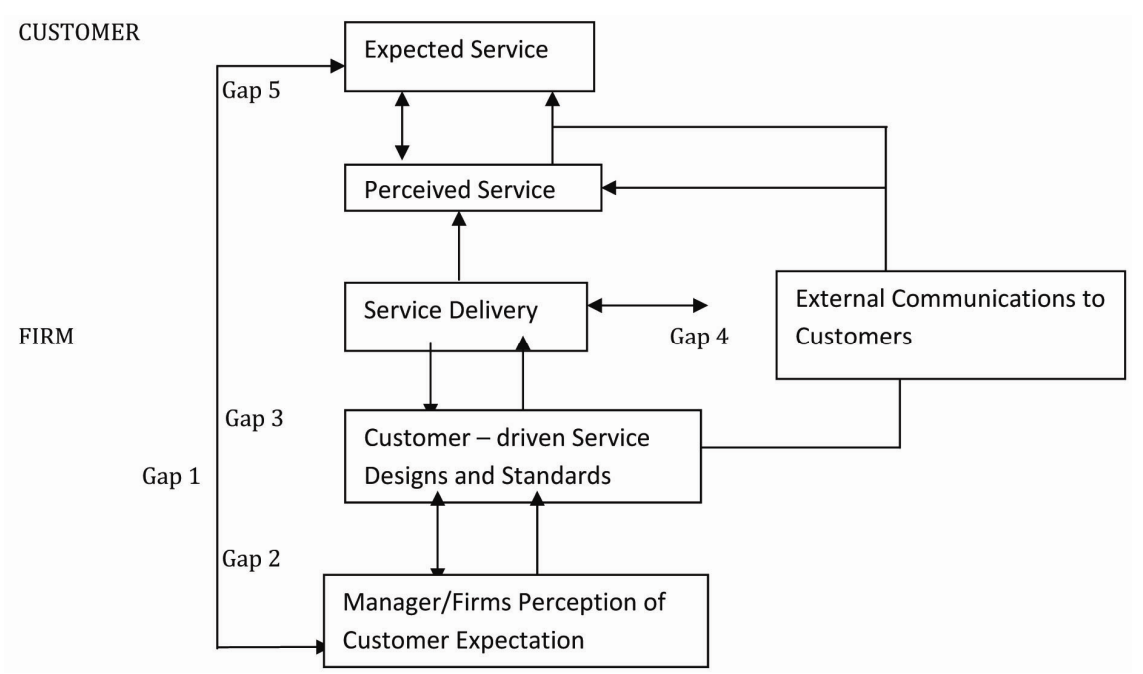

Figure 1. Gaps model of service quality (adapted from Zeithaml, 2003)

Notes. Gap 1 -The Management Perception Gap; this gap means that management perceives the quality expectations inaccurately.

Gap 2- The Quality Specification Gap; this gap assumes that service quality specifications are not consistent with management perceptions of quality expectations.

Gap 3- The Service Delivery Gap; this gap means that quality specifications are not met by performance in the service production and delivery process.

Gap 4- The marketing Communication Gap; this gap means that promises given by market communication activities are not consistent with the service delivered.

Gap 5- The perceived service quality gap; this gap means that the perceived or experienced service is not consistent with the expected service.

The gap model is expected to guide providers in identifying the source of service quality inadequacy and design solution to reduce them (if not total removal) of the gap. This is a way of identifying difference between a service provider and consumer's perception of service delivery. A solution or system that addresses the source of service gaps will go a long way to equate expectation to perception (Amaratunga \& Baldry, 2003).

\subsection{Indicators of Customer/User Satisfaction in High-Rise Buildings}

Ukoha and Beamish (1997) asserted that simple provision of dwelling units or apartment towers does not guarantee successful housing programme in any country, the ability of the living environment to meet and sustain the residents' requirement is the key determinant of the success of housing provision/project. Ukoha and Beamish (1997) found that management and maintenance of the housing units could be a source of 
dissatisfaction to occupiers. Liu (1999) advised on the important of understanding the things that make a building occupant satisfied and/or unsatisfied as this plays a vital role in the formulation of housing policies. The identified indicators that dictate level of satisfaction of housing delivery to tenants include but not limited to repair procedure, timely response to effect repairs, expertise of maintenance staff and quality of repair, and the overall maintenance of the house (Ibem, 2012).

Further examination of the service delivery system based on the indicators allows a wholistic assessment of tenant satisfaction. Earlier study (Satsangi \& Keams, 1992) criticized the effectiveness of tenant survey in housing delivery. The problem is whether tenant satisfaction survey is a good measure for maintenance management performance. The authors argued that conventional tenant satisfaction surveyors often ended in measuring factors outside the control of providers. They suggested a 'reliable' method of tenant's satisfaction that considers among others, that the consumers are not interested in perfect information, there is variance in the degree of satisfaction of different individuals in different situations or circumstances, that housing services lack absolute criteria for satisfaction judgement and there is subjectivity in judgement of service quality depending on culture and social status (Ibem, 2012; Mohit, Ibrahim, \& Rashid, 2010). Despite these criticisms, there has been no satisfactory alternative to tenant satisfaction surveys. Even Satsangi and Keams (1992) recognized some of its merits but suggested modifications. The general consensus is that degree of user satisfaction is an indication of the efficient building maintenance and FM service delivery (Ngo, 1990; Amole, 2009; Fatoye, 2005).

FM services can be provided in-house or outsourced. Where provided in-house, a property/facilities maintenance manager is employed by an organization to co-ordinate the property facilities management activities. In outsourcing, FM services are contracted out to another firm who is responsible to source for the contracted services and its prompt and satisfactory delivery. Outsourcing can be likened to contracting out some specialized services to be provided by the professionals/specialists to enable an organization focus or its primary goal. The axillaries services that are required for effective efficient performance of an organization towards achieving its goal are contracted out to experts, thereby making the organization to focus on its core business. Outsourcing reduces overheads, facilitates saving and ensures better service delivery and promotes clients satisfaction. Today, a number of organisations focused more on cost in the sight of reduced emphases on quality as their reason to outsource FM services as a way of reducing total operational cost (Ibem, 2012). However, there has been rapid dynamic and collaborative relationship by providers with the aim of creating value rather than cutting costs. The trend is leading to the transformation toward value creation for both owners and occupiers of buildings. An unacceptable service quality is costly to both the client and the provider (Ibem, 2012; Mohit et al., 2010; Tenner and Detoro, 1992). Therefore a quality delivery in service provision will turn out to be an all win strategy with benefits to all stakeholders. Cost can be saved when inspection time is reduced, and work is not redone. Heskett, Sasser, and Schlesinger (1999) posited that value is created when the cost of the product/service is far less than the quality of service derived using the Customer Value Equation.

$$
\text { Value }=\frac{\text { Results produced for the client }+ \text { Process quality }}{\text { Price to the client }+ \text { Costs of acquiring the service }}
$$

Value addition result when the denominator is reduced and/or numerator improved/increased.

\subsection{Measurement of Service Quality}

The main objectives of quality service measurement are to achieve improvement in service delivery and meet client's satisfaction. Tenner and DeToro (1992) emphasized ensuring customer satisfaction requires assessment of quality at three different levels of process, output and outcome. They argued against the process and output delivery alone and that it is also good to know what the customer makes of the output. Does the output meet the need and expectation of the users? Tenner and DeToro (1992) concluded that, it is not only output and outcome that remain the final benefit, the process also generates products which are of benefits to other stakeholders in the form of financial return to shareholders, employee's job satisfaction and sustenance of the community in form of social benefit. Therefore, quality measurement system needs to address due effects on all that are concerned.

An understanding of outsourcing in FM service delivery requires a good knowledge of quality service measurement and performance assessment once a provision is in place (Heavisides \& Price, 2001). The long delay in FM service delivery process often results in variation in quality, thus the greater need to measure and or check performance. Measurement fulfills different purposes for both the FM provider and the customer. Kincaid 
(1994) opined that measurement of performance will lead to better understanding of the tasks by FM service providers and give a benchmark of performance assessment among facilities managers. It also reveal any need for change in delivery processes as well as a convincing prove to clients of the standard of what is being done. Finally, service quality measurement fosters a good and harmonious contractual relationship with value addition.

Improving services call for an assurance of meeting the customers' expectation. Amstrong and Baron (1998) emphasized that quality service measurement answers two questions of the worthiness of doing something and how well the thing is done. Quality measurement assesses past achievement and help in decision making and planning for improvement (Harris \& Mongiello, 2001). The importance of service quality measurement becomes obvious and notable when a proactive role of the manager is expected in other to

(i) Ensure meeting customer requirement,

(ii) Provide a benchmark for an industry

(iii) Set standard for comparison

(iv) Justify resource allocation

(v) Give feed back

\subsection{Methods of Measurement of Service Quality}

For service quality measurement, there are various methods or tools that can be adopted. These methods vary in suitability and approaches as well as what they measure. The frequently used method for quality service measurement include a simple approach of asking customers direct questions, identifying their wants, needs and complaints, and maintaining a proactive response system to service delivery that meet the users need (Ismail, Othman, \& Amat, 2010; Kang \& Fredin, 2012; Vladimir \& Marinkovic, 2013). Baggs and Kleiner (1996) stated that such measures could constitute an output performance indicator for quality control and create a basis of the appropriateness of service level from the user's point of view. Asking clients and users questions could rarely give unanimous quality control. To achieve reliability in measurement, both qualitative and quantitative data are to be considered with regard to actual service and the service environment (Kincaid, 1994). The fact that FM services are tangible elements affirmed that the product quality as well as service delivery quality and satisfaction derivable will be better assessed qualitatively. The Service Quality (SERVQUAL) as a quality measurement instrument has been predominantly used to measure consumers' perceptions in customer satisfaction studies (Parasuraman et al., 1990). It has five generic dimensions that include the followings:
a. Tangibility - in terms of physical facilities, equipment and personnel
b. Reliability - relating to the service accuracy
c. Responsiveness - prompt service delivery
d. Assurance-competence, courtesy, and credibility
e. Empathy - access, communication, understanding the customer.

Fatoye (2005) stated that from a best value perspective, the measurement of service quality must take into account customer expectations and perceptions of service. Robinson (1999) concludes that there is little or no consensus on the best way to measure service quality. Therefore a balance of qualitative and quantitative measurement of service quality is inevitable. The more adopted methods of service quality measurement are discussed in the following sections.

\subsubsection{Expectation Compared to Perception (Gap Score)}

Gronroos (1990) support the notion that service quality, as perceived by customers, stems from a comparison of what they feel service firms should offer with their perceptions of the services provided. Service quality gap is therefore identified as the discrepancy between consumers' expectation and perception of services/products and this indicate satisfaction level.

\section{Service Quality Score = Mean score of expectations - Mean score of perceptions}

The term "expectation" is used differently in quality and satisfaction literatures. Expectation in satisfaction refers to predictions made by consumers about what is likely to happen in a transaction while it is viewed as desire of consumers in service quality. The consensus is that expectations are consumer-defined probabilities of the occurrence of positive and negative events of a behavior (Vladimir \& Marinkovic, 2013). 


\subsubsection{Benchmarking}

Varcoe (1993) suggested the integration of benchmarking and performance measurement in the strategy of quality service delivery. The comparison of performance against established comparable or set yardstick is referred to as Benchmarking. This means the performance of identified comparable is a benchmark/yardstick to measure and judge the performance of a subject. Benchmarking is seen as a means of identifying improvement opportunities as well as monitoring the performance of competitors (Young, 1993). Camp (1989) defines benchmarking as "the continuous process of measuring products, services and practices against the toughest competitor or those companies recognized as industry leaders, it is a search for industry best practices that leads to superior performance". Benchmarking, as a term, was originally used by Land Surveyors to compare elevations (Kouzmin, Loffler, Klages, \& Korac-Kakabadse, 1999). Horvath and Herter (1992) in same line with Camp (1989) defined benchmarking as a continuous systematic process of measuring products, services and practices against organizations regarded to be superior with the aim of rectifying any performance gaps. It aims at identifying competitive targets and establishes means of improvement. It is of great value, to adopt consistent measurement procedure across a service in order to indicate reliable areas of strengths and weaknesses (Ennew, Read \& Binks, 1993).

\subsubsection{Performance Evaluation}

This call for the evaluation of the services of the facilities manager as well as the facility itself, it is the performance evaluation of building facility from any perspective. It is more dispassionate than scientific. It study economics of maintenance and evaluate the design, construction and materials. Building performance evaluation can be achieved through the use of 'Balanced Score Card (BSC) (Kang \& Fredin, 2012) or Key Performance Index (KPI)

\subsubsection{Satisfaction Index}

The Satisfaction Index was also employed to really establish the satisfaction level using the four-point Likert scale system to ascribe value to qualitative variables of satisfaction level

$$
\begin{aligned}
& \text { Satisfaction index }(\text { S.I })=\underline{\text { sum total of actual score by respondents }} \times 100 \\
& \text { Maximum possible score by respondents } \\
& \text { Thus, } S . I=\underline{v}_{\underline{1}} \underline{\underline{r}}_{1} \underline{+} \underline{v}_{\underline{2}} \underline{\underline{r}}_{2}+\underline{v}_{3} \underline{\underline{r}}_{3}+\ldots \ldots+\underline{v}_{\underline{n}} \underline{\underline{\underline{r}}} \underline{\underline{n}} \\
& v_{h} N
\end{aligned}
$$

Where $\mathrm{v}_{1}, \mathrm{v}_{2}, \mathrm{v}_{3}, \ldots \mathrm{v}_{\mathrm{n}}$ are the values representing satisfaction level variables on the Likert scale, $\mathrm{r}_{1}, \mathrm{r}_{2}, \mathrm{r}_{3} . . \mathrm{r}_{\mathrm{n}}$ are number of respondents that chooses the corresponding values of satisfaction level variable, $v_{h}$ is the highest value of the satisfaction level variables expected and $\mathrm{N}$ represent the sample (respondents). The satisfaction index was calculated for both estates and for each service.

\section{Methodology}

Purposive sampling was adopted to select the estates that have enough facilities relevant to this studies and where FM is practiced. This is because some of the public estates are not provided with the adequate facilities. Two case studies were used for the study and they are Eko Court Complex and Boyle Street Estate. Eko Court is located in Victoria Island, while Boyle Street Estate is located in Lagos Island both in Lagos state. Occupants of 73 flats out of 156 were selected randomly in Eko Court while the entire occupants of Boyle street estate (38) flats were studied. Combinations of closed and open-ended questionnaire were administered to the resident of the estates. This study adopted the Service Quality (Gap) Score and Satisfaction Index methods in measuring residents (customer satisfaction)

The use of 4 point Likert Scale was adopted to rank the degree of importance and satisfaction. The highest value of 4 point was ascribed to highest level of importance and satisfaction, while the least level of no importance/satisfaction was ascribed 1 point. The conditions for service quality were listed in table 3 under five criteria of quality measurement which includes Tangibility, Reliability, Responsiveness, Assurance and Empathy (Feehi, Adjei, \& Osarenkhoe, 2013; Parasuraman, Zeithaml, \& Berry, 1991; Young, 2004). Satisfaction index and mean item score were calculated to find the difference in expectation and perception of service delivery. Descriptive statistics of frequency distribution and measure of central tendency were used to analyse the responses. The service score gap and satisfaction index were ranked to identify the level of satisfaction derived in respect of each item of consideration. 


\section{Data Analysis and Discussion}

The study revealed that some FM services were outsourced (cleaning, security and refuse disposal and lift operation), others that are being managed in-house falls within the managerial capacity of the property managers of the case studies and where core competence is required, recourse is made back to the professionals. The deduction is that in as much as outsourcing is a welcome and well thought of option in contemporary property/facility management, there are still some services in the case study that are provided in-house (Table 1). The outsourced FM services in the case study is in line with the trend of adoption of outsourcing of FM services in Nigeria. This finding agree with Ibem (2012) that organizations are focusing more on their core goal and competencies. It will also lead to acceptable quality service delivery (Mohil et al., 2010; Tenner \& DeToro, 1992). The finding answers the objective 1 of the study with respect to FM service delivery method.

The study further shows that residents of the case studies feel satisfied with the level of quality of service they are being provided. However, those in Eko Court exhibited more satisfaction with general quality of services and their level of satisfaction is higher than that of those in Boyle Street in terms of percentage. This infers that the quality of services provided in Eko Court is relatively higher than what is obtainable in Boyle Street.

Table 1. Identification of outsourced services/facilities in the estates

\begin{tabular}{|c|c|c|c|c|c|}
\hline & Services & Eko Court & & Boyle's Str & \\
\hline & & Frequency & Percentage & Frequency & Percentage \\
\hline $\mathbf{A}$ & Water & & & & \\
\hline & Owner/Developer & 15 & 26.3 & 17 & 63 \\
\hline & Residents & 14 & 24.6 & 0 & 0 \\
\hline & Manager & 11 & 19.3 & 5 & 18.5 \\
\hline & Outsourced to Service Provider & 16 & 28.1 & 0 & 0 \\
\hline & Total & 56 & 98.2 & 22 & 81.5 \\
\hline B & Electricity & & & & \\
\hline & Owner/Developer & 21 & 36.8 & 12 & 44.4 \\
\hline & Residents & 8 & 14 & 5 & 18.5 \\
\hline & Manager & 10 & 17.5 & 5 & 18.5 \\
\hline & Outsourced to Service Provider & 18 & 31.6 & 0 & 0 \\
\hline & Total & 57 & 100 & 22 & 81.5 \\
\hline C & Lift/Elevator & & & & \\
\hline & Owner/Developer & 14 & 24.6 & 13 & 48.1 \\
\hline & Residents & 7 & 12.3 & 0 & 0 \\
\hline & Manager & 18 & 31.6 & 5 & 18.5 \\
\hline & Outsourced to Service Provider & 18 & 31.6 & 9 & 33.3 \\
\hline & Total & 57 & 100 & 27 & 100 \\
\hline D & Cleaning/Pest Control & & & & \\
\hline & Owner/Developer & 21 & 36.8 & 13 & 48.1 \\
\hline & Residents & 7 & 12.3 & 0 & 0 \\
\hline & Manager & 11 & 19.3 & 5 & 18.5 \\
\hline & Outsourced to Service Provider & 18 & 31,6 & 9 & 33.3 \\
\hline & Total & 57 & 100 & 27 & 100 \\
\hline $\mathbf{E}$ & Refuse Disposal & & & & \\
\hline & Owner/Developer & 19 & 33.3 & 8 & 29.6 \\
\hline & Residents & 2 & 3 & 0 & 0 \\
\hline & Manager & 18 & 31.6 & 10 & 37 \\
\hline & Outsourced to Service Provider & 18 & 31.6 & 9 & 33.3 \\
\hline & Total & 57 & 100 & 27 & 100 \\
\hline $\mathbf{F}$ & Security & & & & \\
\hline & Owner/Developer & 13 & 22.8 & 4 & 14.8 \\
\hline & Residents & 14 & 24.6 & 9 & 33.3 \\
\hline & Manager & 11 & 19.3 & 5 & 18.5 \\
\hline & Outsourced to Service Provider & 19 & 33.3 & 9 & 33.3 \\
\hline & Total & 57 & 100 & 27 & 100 \\
\hline G & General Repairs & & & & \\
\hline & Owner/Developer & 9 & 15.8 & 9 & 33.3 \\
\hline & Residents & 17 & 29.8 & 0 & 0 \\
\hline & Manager & 11 & 19.3 & 4 & 14.8 \\
\hline & Outsourced to Service Provider & 20 & 35.1 & 14 & 59.9 \\
\hline & Total & 57 & 100 & 27 & 100 \\
\hline
\end{tabular}

Source: Field Survey 2012. 
The difference in level of satisfaction between the two estates is attributed to the differences in location of the two estates and the social class. The residents of Eko Court Complex are predominantly high income class occupants. The expectation of the residents with regards to each service is therefore a factor. This finding agrees with Fatoye (2009) that income level and social status dictates quality in housing provision with the assertion that there is corresponding increase in housing quality from low income to the high income estates. The findings also agree with Liu (1999) that difference in the level of satisfaction that is reflected from perception is a function of social status of the subjects. Furthermore, the residents through their responses are satisfied with service provided though there is room for improvement. The residents are unanimous in their level of satisfaction both in respect of each service and the general aggregate satisfaction level. Moderate level of satisfaction is derived from the facilities and support services. This finding agreed with Mohd-Tawil, Ramly, Che-Ani, Ismar, and Zain (2005); and Mohit et al., (2010) that high percentage of occupants of public estate are moderately satisfied with the quality of FM service they enjoyed more than the physical features of their dwelling units and the environment. The level of expectation met by the service providers was also sought in both case studies, the results also show that a higher percentage was recorded in Eko Court when compared with Boyle Street; hence further authenticating the fact that resident of Eko Court enjoys a better service provision than those in Boyle Street. The level of expectation and the perception of the residents with respect to quality of services from the providers were assessed for both case studies. There were differences in the expectation and perception of service quality of services in the estates, the overall analysis suggest that the service provision is satisfactory, though there are areas for improvement.

On an informal discussion with some residents and the staff of FM firms, the researcher found that performance measurement is being done through benchmarking where both the residents and facilities manager compare the service provisions with their neighbouring properties. The Facilities Managers try to compete in providing what they considered as quality service in comparison with other buildings they serve and other buildings serviced by other firms. The resident on the other hand compares what they benefit with what occupants of adjoining properties enjoy in term of FM service delivery and uses it to demand for better service from or praise their provider. This approach does not really consider the initial or present expectation of residents. The study suggests that service quality measurement in FM should have consideration for consumer expectations and perceptions of service. This agrees with Fatoye and Odusami (2009) that, to different criterion is attached different level of satisfaction by occupiers of residential houses. Therefore the customers expectation of each criterion or indicator of satisfaction be identified and facility managers are to strive to meet such expectation. This study found that the current service delivery in the selected properties in term of quality did not fully meet with the users' expectations (expectation is higher than perception of actual service delivered). Nevertheless, the quality is satisfactory and acceptable as shown by the satisfaction index of $75 \%$ and above for all services and in both estates (Table 2).

Table 2. Satisfaction index for each of the services

\begin{tabular}{lllll}
\hline Services & Eko Court & Rank & Boyle's street & Rank \\
\hline Water & 0.824 & 4 & 0.852 & 2 \\
Electricity & 0.715 & 7 & 0.75 & 7 \\
Lift/Elevator & 0.851 & 1 & 0.889 & 1 \\
Cleaning/Pest Control & 0.825 & 2 & 0.796 & 4 \\
Refuse Disposal & 0.825 & 3 & 0.806 & 3 \\
Security & 0.789 & 5 & 0.769 & 6 \\
General Repairs & 0.754 & 6 & 0.796 & 5 \\
\hline
\end{tabular}

Source: Field Survey 2012.

26 indicators were used to assess performance of service provider across five dimensions using a four (4) point Likert Scale of ranking for both customer expectations and perceptions. The service quality score which is the difference between weighted score of expectation and weighted score of perception were calculated for all the 26 indicators. The value is greater than zero (0) for all attributes. This answers objective 2 suggesting that FM service firms do not meet users' expectation at $100 \%$ in any of the 26 items. Service quality score for seven (7) indicators out of the 26 quality indicators were rated below average with the gap score $\geq 2$ (table 3 ) ranking 20 26. There is need for the service providers to improve in such areas to be able to meet the clients' satisfactory level/requirements. 
Table 3. The mean value of the expectation and perception of the service quality

\begin{tabular}{|c|c|c|c|c|c|}
\hline $\mathrm{S} / \mathrm{N}$ & Evaluation Indicator & $\begin{array}{l}\text { Mean } \\
\text { (Expectation) }\end{array}$ & $\begin{array}{l}\text { Mean } \\
\text { (Perception) }\end{array}$ & $\begin{array}{l}\text { Gap } \\
(\mathrm{Me}-\mathrm{Mp})\end{array}$ & Rank \\
\hline 1 & $\begin{array}{l}\text { A5 - All kinds of promotion/advertisement materials } \\
\text { should be fashionable and of excellent quality }\end{array}$ & 3.375 & 1.125 & 2.625 & 26 \\
\hline 2 & $\begin{array}{l}\text { B4- All the promises given to the residents should be } \\
\text { executed on time }\end{array}$ & 3.375 & 1 & 2.375 & 25 \\
\hline 3 & $\begin{array}{l}\text { A3 - All the supporting equipment with which to provide } \\
\text { the service should be in good condition }\end{array}$ & 3.75 & 1.5 & 2.25 & 24 \\
\hline 4 & $\begin{array}{l}\text { A1- The facilities management company should maintain } \\
\text { all facilities in good condition }\end{array}$ & 3.875 & 1.625 & 2.25 & 23 \\
\hline 5 & $\begin{array}{l}\text { B1- All the services should be delivered in time to } \\
\text { residents in the estates }\end{array}$ & 3.25 & 1.125 & 2.125 & 22 \\
\hline 6 & B5- Services should be delivered effectively & 3.25 & 1.25 & 2 & 21 \\
\hline 7 & $\begin{array}{l}\text { B2- All kinds of financial data and information of residents } \\
\text { should be recorded correctly }\end{array}$ & 3.375 & 1.375 & 2 & 20 \\
\hline 8 & $\begin{array}{l}\text { B3- All kinds of fees should be reasonable, the account } \\
\text { statement should be correct }\end{array}$ & 3 & 1.125 & 1.875 & 19 \\
\hline 9 & E3- Should provide the personalized/customized service & 3.125 & 1.375 & 1.75 & 18 \\
\hline 10 & $\begin{array}{l}\text { A2 - All the staff should be neat in appearance and have } \\
\text { proper behavior }\end{array}$ & 4 & 2.25 & 1.75 & 17 \\
\hline 11 & $\begin{array}{l}\text { E4- The facilities management staff should consult with } \\
\text { the residents before they set the regulations for } \\
\text { management of the estate }\end{array}$ & 3.375 & 1.75 & 1.625 & 16 \\
\hline 12 & E1- Should provide the 24-hour service & 3.375 & 1.75 & 1.625 & 15 \\
\hline 13 & E2- Understand the resident needs & 3.5 & 2 & 1.5 & 14 \\
\hline 14 & $\begin{array}{l}\text { C3- The facilities management staffs should respond to the } \\
\text { residents request no matter how busy they are }\end{array}$ & 3 & 1.5 & 1.5 & 13 \\
\hline 15 & $\mathrm{C} 1$ - Prompt response to the residents request & 3.375 & 1.875 & 1.5 & 12 \\
\hline 16 & D3- All the documents and services provided are correct & 3 & 1.625 & 1.375 & 11 \\
\hline 17 & $\begin{array}{l}\text { C4- The communication channels between staffs and the } \\
\text { residents should be kept open (e.g webpage, e-mail, } \\
\text { telephone etc) }\end{array}$ & 2.875 & 1.5 & 1.375 & 10 \\
\hline 18 & $\begin{array}{l}\text { A4 - The administrative and public activity area should be } \\
\text { kept clean, aesthetic and excellent at all the time }\end{array}$ & 3 & 1.625 & 1.375 & 9 \\
\hline 19 & $\begin{array}{l}\text { E6- The management staff should inform the resident } \\
\text { when the data on residents is found irregular }\end{array}$ & 3.375 & 2.25 & 1.125 & 8 \\
\hline 20 & D4- The privacy of the resident are protected & 3.125 & 2 & 1.125 & 7 \\
\hline 21 & C5- Should handle all the complaints effectively & 2.875 & 1.875 & 1 & 6 \\
\hline 22 & $\begin{array}{l}\text { D5- All the residents fully understand the content of the } \\
\text { service, method of delivery, fee charged and service } \\
\text { standard }\end{array}$ & 2.875 & 2 & 0.875 & 5 \\
\hline 23 & D2- The operation of the company should be transparent & 2.875 & 2 & 0.875 & 4 \\
\hline 24 & $\begin{array}{l}\mathrm{C} 2 \text { - The facilities management staffs should understand } \\
\text { the residents attitude and act accordingly }\end{array}$ & 2.75 & 1.875 & 0.875 & 3 \\
\hline 25 & $\begin{array}{l}\text { D1- Managerial staff and supporting staff should have } \\
\text { adequate technical knowledge }\end{array}$ & 2.875 & 2.125 & 0.75 & 2 \\
\hline 26 & $\begin{array}{l}\text { E5 - Should record the residents' complaint and make } \\
\text { effort for improvement and conduct regular visits }\end{array}$ & 3.125 & 2.5 & 0.625 & 1 \\
\hline
\end{tabular}

Source: Field Survey 2012.

In agreement with Amaratunga and Baldry (2003), FM providers should identify the expectation of users and communicate with users on quality service delivery. This finding answers objective 3 and 4 .

In other to address the important areas of deficiency, FM providers should understand user's point of view and identify where to concentrate so as to improve quality towards meeting the consumer satisfaction requirement and at the same time avoiding allocation of resources to providing services that are least expected and which may not pay off. Improving dissatisfying indicators becomes a priority for the facilities managers to devote more attention. Service recovery is another way of reducing dissatisfaction. 


\section{Conclusion}

The study identified that services are outsourced and the ones that were not outsourced are under the management of the consultant property manager who takes responsibility for the provision of such services from the service charge account for the estates. This in a way could be likened to outsourcing since the property manager will not provide the services himself but rather look for technicians where necessary or contract the work out to other professionals. From the study, the residents do receive satisfactory Facilities Management services. The main finding of this study reveal that customer's expectations of service quality is higher and the service delivery by the service providers is below customers' expectations. Hence, need to improve in the area of quality service significantly. On the basis of the findings of the study, the followings were recommended for quality service delivery; improve standardization of services; customize services; strengthen service recovery and reliability and manage service commitment effectively. FM Service providers should identify the most expected service(s) and understand the psyche of the users in order to meet the customers' required satisfaction rather than devoting resources to least expected services.

\section{Limitation}

The study examines user satisfaction in residential high-rise buildings; it identifies the procedure and problems as well as unique constraints of housing maintenance and management, which affect user satisfaction. The study was aimed at determining satisfaction level and quality of service delivery from the perspective of the residents/occupants of the public residential estates in terms of the facilities provided and services being provided for these estates. The purpose of the study was also to examine if the resident of high rise buildings received satisfactory service performance from the FM service provider. The case studies are the Eko Court Complex at Victoria Island and the 38 flats residential estate on Boyle Street Onikan, both developed by the Lagos State Development and property Corporation, an organ of Lagos State Government. The findings may therefore not reflect totally the situation in private residential towers in Lagos.

\section{References}

Amaratunga, D., \& Baldry, D. (2003). A conceptual framework to measure facilities management performance. Propert Management, 21(2), 171-189. http://dx.doi.org/10.1108/02637470310478909

Amole, D. (2009). Residential satisfaction in student housing. Journal of Environmental Psychology, 29, 76-85. http://dx.doi.org/10.1016/j.jenvp.2008.05.006

Amstrong, M., \& Baron, A. (1998). Performance Management,The New Realities. London: Institute of Personnel and Development.

Baggs, S. C., \& Kleiner, B. H. (1996). How to Measure Customer Service Effectively. Managing Service Quality, 6(1), 36-39. http://dx.doi.org/10.1108/09604529610108126

Camp, R. C. (1989). Benchmarking—The Search for Industry Best Practices that lead to Superior Performance. Milwankee, WI: ASQS Quality Press.

Ennew, G., Read, G., \& Binks, M. (1993). Importance-Performance Analysis and the Measurement of Service. European Journal of Science, 27(2), 69-70.

Fatoye, E. O. (2005). An assessment of occupiers' satisfaction on Quality Performance of Public Residential Estates. (M. Sc.). University of Ibadan, Nigeria.

Fatoye, E. O., \& Odusami, K. T. (2009). Occupants Satisfaction Approach to Housing Perfromance Evaluation: the Case of Nigeria. Paper presented at the RICS COBRA Research Conference, University of Cape Town.

Feehi, O. A., Adjei, S. J., \& Osarenkhoe, A. (2013). Service quality in the Banking Sector in Ghana. International Journal of Marketing Studies, 5(2).

Francescato, G., Weidemann, S., \& Anderson, J. R. (1989). Evaluating the Built Environment from the Users' Point of View: An Attitudinal Model of Residential Satisfaction. In W. F. E. Preiser (Ed.), Building Evaluation (pp. 181-198). New York: Plenum Press. http://dx.doi.org/10.1007/978-1-4899-3722-3_14

Giese, J. L., \& Cote, J. A. (2002). Defining Customer Satisfaction. Academy of Marketing Science Review, 2000(1), 1-23.

Gronroos, C. (1990). Service management and marketing: Lexingtonng Books.

Harris, P. J., \& Mongiello, M. (2001). Key Performance Indicatos in European Hotel Property: General Managers Choices and Company Profiles. International Journal of Contemporary Hospital Management, 13(3), 120-127. http://dx.doi.org/10.1108/09596110110388909 
Heavisides, B., \& Price, L. (2001). Input versus Output-based performance measurement in NHS-the current situation. Facilities, 19(10), 344-356. http://dx.doi.org/10.1108/EUM0000000005533

Heskett, J. L., Sasser, W. E., \& Schlesinger, L. A. (1999). The Service Profit Chain. New York: The Free Press.

Horvath, P., \& Herter, N. R. (1992). Benchmarking: Comparison with the best of the best. Controlling, 4(1), 4-11.

Ibem, E. O. (2012). Residents' perception of the quality of public housing in urban areas in Ogun State, Nigeria. International Journal of Quality and Reliability Management, 29(9), 1000-1018. http://dx.doi.org/10.1108/02656711211272917

Ismail, S., Othman, M. H., \& Amat, S. C. (2010). A study on service quality of Refurbishment Contractor towards Clients Satisfaction. Paper presented at the International Conference on Science and Social Research, Kuala Lumpur, Malaysia.

Jeffres, L. W., \& Dobos, J. (1995). Separating Peoples's Satisfaction with Life and Public Perception of the Quality of Life in the Environment. Social Indicators Research, 34, 181-211. http://dx.doi.org/10.1007/BF01079196

Johnston, R., \& Clark, G. (2005). Service operations management: Improving service delivery. Prentice Hall.

Kang, G., \& Fredin, A. (2012). The balanced score card: the effects of feedback on performance evaluation. Management Research Review, 35(7), 637-661. http://dx.doi.org/10.1108/01409171211238848

Kincaid, D. G. (1994). Measuring Performance in Facilities Management. Facilities, 12(6), 17-20. http://dx.doi.org/10.1108/02632779410060265

Kouzmin, A., Loffler, E., Klages, H., \& Korac-Kakabadse, N. (1999). Benchmarking and performance measurement in public sectors: Towards learning for agency effectiveness. International Journal of Public Sector Management, 12(2), 121-144. http://dx.doi.org/10.1108/09513559910263462

Ling, F. Y. Y., \& Chong, C. L. K. (2005). Design-and-build contractors' service quality in public projects in Singapore. Building and Environment, 40(6), 815-823. http://dx.doi.org/10.1016/j.buildenv.2004.07.017

Liu, A. M. M. (1999). Residential Satisfaction in Housing Estates: A Hong Kong Perspective. Automation in Construction, 8, 511-524. http://dx.doi.org/10.1016/S0926-5805(98)00098-3

Mohd-Tawil, N., Ramly, A., Che-Ani, A. I., Ismar, I. M. S., \& Zain, M. F. M. (2005). Management Difficulties in Managing High Rise Residential Complexes in Malaysia: The Service Charge Aspect. Recent Advances in Energy and Research, 31-35.

Mohit, M. A., Ibrahim, M., \& Rashid, Y. R. (2010). Assessment of residential satisfaction in newly designed public low-cost housing in Kuala Lumpur, Malaysia. Habitat International, 34(1), 18-27. http://dx.doi.org/10.1016/j.habitatint.2009.04.002

Ngo, M. (1990). Asset Management-a methodology of establishing standard maitenance standard. In V. Ireland \& G. Runesan (Eds.), Building Economics and Construction Management (Vol. 3, pp. 149-153): University of Sydney.

Parasuraman, A., Zeithaml, V. A., \& Berry, L. L. (1990). Delivering quality service: balancing customer perceptions and expectations. New York: The Free Press.

Parasuraman, A., Zeithaml, V. A., \& Berry, L. L. (1991). Refinement and Reassessment of the SERVQUAL Scale. Journal of Retailing, 67, 420-450.

Parasuraman, A., Zeithaml, V. A., \& Berry, L. L. (1998). SERVQUAL: A Multiple-item scale for measuring consumer perceptions of service quality. Journal of Retailing, 64, 12-40.

Robathan, P. (1996). Intelligent Building Performance. In K. Alexander (Ed.), Facilities Management: Theory and Practice (pp. 98-108). London: spon press.

Satsangi, M., \& Keams, A. (1992). The use and interpretation of tenant satisfaction in British social housing. Environmental Planning C. Government and Policy, 10(13), 317-331. http://dx.doi.org/10.1068/c100317

Tenner, A. R., \& DeToro, I. J. (1992). Total quality management. Three steps to continuous improvement. Reading, Massachusetts: Addison-Wesley.

Torbika, Z. M., \& Stroh, R. C. (1989). Inpact of Total Quality Management on Home Buyers Satisfaction. Journal of Construction Engineering and Management, 125(3), 198-203. 
http://dx.doi.org/10.1061/(ASCE)0733-9364(1999)125:3(198)

Ukoha, O., \& Beamish, J. O. (1997). Assessment of residents' satisfaction with public housing in Abuja, Nigeria. Habitat International, 21, 445-460. http://dx.doi.org/10.1016/S0197-3975(97)00017-9

Varcoe, B. J. (1993). Facilities Performance: Achieving Value for Money through Performance Measurement and Benchmarking. Property Management, 11(4), 301-307. http://dx.doi.org/10.1108/02637479310048114

Vladimir, S., \& Marinkovic, V. (2013). Patient care, satisfaction and service quality in health care. International Journal of Consumer Studies, 37(3), 312-319. http://dx.doi.org/10.1111/j.1470-6431.2012.01132.x

Young, F. (2004). Integrated Operational Services: Meeting continuously changing needs and expectations. Facilities, 22(13), 373-376. http://dx.doi.org/10.1108/02632770410563095

Young, S. (1993). Checking performance with competitive benchmarking. Professional Engineering, 14-15.

\section{Copyrights}

Copyright for this article is retained by the author(s), with first publication rights granted to the journal.

This is an open-access article distributed under the terms and conditions of the Creative Commons Attribution license (http://creativecommons.org/licenses/by/3.0/). 